\title{
Analisis Faktor-Faktor Yang Dapat Mempengaruhi Keputusan Konsumen Dalam Mengambil Kredit Kpr Pada PT. Bank Tabungan Negara Cabang Jember
}

\author{
Haifa \\ STIE Mandala, Jember
}

\begin{abstract}
This study aims to determine the effect of consumer decisions in taking mortgages at Bank Tabungan Negara Tbk Jember Branch. This study uses Chi-square analysis to determine the relationship between factors that influence consumer behavior (which consists of (1) requirements, (2) credit interest rates and (3) credit installment subsidies) also uses Coeficient Contingency analysis to know the effect on decisions consumers in taking mortgage loans at PT. Bank Tabungan Negara Tbk Jember Branch the population in this study were consumers who took mortgage loans at PT. State Savings Bank (Persero) Tbk. Jember Branch. The total population is 200 respondents where the sample uses the non probability quota sampling method which is a sampling method in which the subjects to be studied are determined in advance of the amount. The number of samples is 50\% of the number of respondents as many as 100 The results of the study show that Based on the results of calculations using Chi-square analysis and Coeficient Contingency analysis, the credit application requirements, credit interest rates and credit disbursement realization factors, there is a significant relationship and influence on customer decisions in taking credit at PT. Bank Tabungan Negara Tbk Jember branch
\end{abstract}

Keywords: Consumer Decisions, Consumer Behavior, Credit Interest Rates

\section{Pendahuluan}

Suatu sistim keseluruhan dari kegiatan usaha yang ditujukan untuk merencanakan, menentukan dan mendistribusikan barang atau jasa yang diproduksi dengan tujuan dapat menarik minat konsumen disebut pemasaran. Dengan demikian kegiatan pemasaran tidaklah hanya sekedar menjual produk atau jasa melainkan segala aktivitas yang berhubungan dengan produk atau jasa sejak barang tersebut diproduksi hingga ketangan konsumen sebagai pemakai akhir produk. Kegiatan pemasaran harus juga dapat memberikan kepuasan tersendiri terhadap konsumen, atau konsumen mempunyai image yang baik terhadap perusahaan, untuk itu harus diterapkan konsep promosi yang berorientasi kepada 
konsumen. Konsep pemasaran tersebut menurut Swasta (2002:199) mempunyai tiga unsur pokok yaitu orientasi kepada konsumen, penyusunan kegiatan secara integral dan kepuasan konsumen.

Dari uraian di atas maka jelaslah bahwa konsumen adalah raja bagi perusahaan, itulah sebabnya mengapa penting bagi perusahaan untuk selalu mengamati dan melakukan analisis yang mendalam terhadap analisis konsumen agar perusahaan dapat lebih mengetahui apa yang diinginkan dan yang dibutuhkan oleh konsumen untuk kemudian diterapkan dalam usaha mempromosikan produk perusahaan. Perilaku konsumen dipengaruhi oleh empat variabel yaitu faktor budaya, faktor sosial, faktor pribadi dan faktor psikologis. Selain faktor-faktor diatas, masih terdapat beberapa faktor lain yang dapat mempengaruhi perilaku konsumen dalam mengambil keputusan, namun pihak perusahaan tidak dapat menjangkau atau tidak mempunyai peran dalam mempengaruhinya. Adapun faktorfaktor lain yang dapat mempengaruhi perilaku konsumen khususnya dalam mengambil kredit perumahan antara lain adalah faktor persyaratan kredit, faktor suku bunga pinjaman dan faktor subsidi angsuran kredit. Hasil penelitian terdahulu seperti yang telah dibahas Rani Armadani dalam penelitiannya yang berjudul Analisis Faktor-faktor Yang Mempengaruhi Perilaku Nasabah Dalam Menabung Pada PT. Bank Rakyat Indonesia (Persero) Cabang Jember, maka dapat ditarik suatu kesimpulan sebagai berikut :

Berdasarkan hasil perhitungan dengan menggunakan alat analisis Chikuadrat, maka faktor suku bunga, faktor pelayanan dan faktor fasilitas terdapat hubungan yang signifikan terhadap keputusan responden dalam menabung pada PT. Bank Rakyat Indonesia (Persero) cabang Jember, hal tersebut dibuktikan dengan hasil analisis bahwa nilai $X^{2}$ (hitung) $<X^{2}$ (tabel), dimana nilai $X^{2}$ (hitung) dari faktor suku bunga sebesar 2,24, nilai $\mathrm{X}^{2}$ (hitung) dari faktor pelayanan sebesar 1,44 dan untuk $\mathrm{X}^{2}$ (hitung) dari faktor fasilitas sebesar 2,08, sedangkan $\mathrm{X}^{2}$ (tabel) sebesar 16,919 .

Berdasarkan hasil perhitungan dengan menggunakan alat analisis Coeficient Contingency, faktor-faktor yang mempengaruhi keputusan responden dalam menabung pada PT. Bank Rakyat Indonesia (Persero) cabang Jember, diperoleh 
hasil yaitu faktor suku bunga sebesar 0,481, faktor pelayanan sebesar 0,387 dan faktor fasilitas sebesar 0,458. Oleh karena nilai-nilai hasil perhitungan tersebut masih dibawah 0,5 maka faktor-faktor tersebut dinyatakan memiliki hubungan yang positif namun lemah. Sedangkan diantara ketiga faktor diatas yang paling dominan adalah faktor suku bunga yaitu memiliki nilai $\mathrm{C}$ sebesar $=0,481$.

PT. Bank Tabungan Negara (Persero) Tbk merupakan satu dari sekian banyak perbankan milik pemerintah yang beroperasi di wilayah kabupaten Jember. Adapun produk yang paling banyak diminati oleh konsumen yaitu jasa Kredit Pemilikan Rumah (KPR). Perbankan ini telah memberikan beberapa persyaratan kepada calon konsumen yang akan menggunakan jasa Kredit Pemilikan Rumah tersebut. Namun masih terdapat beberapa faktor lain yang dapat menarik keputusan konsumen dalam mengambil kredit antara lain yaitu faktor persyaratan yang mudah, faktor suku bunga kredit dan faktor subsidi angsuran kredit.

Berdasarkan keterangan diatas maka timbul suatu perumusan masalah yaitu (a) apakah faktor-faktor yang terdiri dari (1) persyaratan, (2) suku bunga kredit dan (3) subsidi angsuran kredit berpengaruhi terhadap keputusan konsumen dalam mengambil kredit KPR? (b) faktor manakah yang paling dominan di dalam mempengaruhi perilaku konsumen dalam mengambil kredit KPR?.

\section{Tinjauan Pustaka}

\section{Pengertian Pemasaran}

Pemasaran adalah sistem keseluruhan dari kegiatan-kegiatan usaha yang ditujukan untuk merencanakan, menentukan harga, mempromosikan dan mendistribusikan barang atau jasa yang dapat memuaskan kebutuhan konsumen yang potensial.

\section{Faktor-faktor Ekstern Yang Mempengaruhi Perilaku Konsumen menurut} Kotler (2001 : 231) antara lain adalah sebagai berikut :

\section{Kebudayaan}

Kebudayaan sifatnya sangat luas dan menyangkut segala aspek kehidupan manusia. Kebudayaan adalah sangat kompleks yang menyangkut pengetahuan, kepercayaan, kesenian, moral, hukum adat istiadat dan kebiasaan-kebiasaan yang didapat manusia sebagai anggota masyarakat. Kebudayan terdiri dari segala sesuatu 
yang dipelajari dari pola-pola perilaku yang normatif, yaitu mencakup segala cara atau pola pikir, merasakan dan bertindak.

\section{Sub Budaya}

Setiap budaya mempunyai kelompok-kelompok sub budaya yang lebih kecil, yang merupakan identifikasi dan sosialisasi yang khas untuk perilaku anggotanya. Minat seseorang akan berbagai jenis barang akan dipengaruhi oleh kebangsaan, agama, ras, dan latar belakang geografis.

\section{Kelas Sosial}

Sebenarnya setiap masyarakat menampilkan lapisan-lapisan sosial. Lapisanlapisan sosial ini kadang berupa sebuah sistem kasta yang berbeda memikul peranan tertentu dan mereka tidak bisa mengubah keanggotaan kastanya. Malah lebih sering lapisan sosial itu berupa kelas sosial yang mempunyai beberapa ciri, antara lain ialah:

1) Orang yang berada dalam kelas sosial cenderung lebih berperilaku serupa dari pada orang yang berbeda dari kelas sosial yang berbeda.

2) Seseorang di pandang mempunyai pekerjaan yang rendah atau tinggi sesuai dengan kelas sosialnya.

3) Kelas kekayaan, pendidikan, dan orientasi terhadap nilai dari pada hanya berdasarkan sebuah variable.

4) Seseorang mampu berpindah dari kelas sosial ke kelas sosial yang lain, ke atas dan ke bawah dalam masa hidupnya.

\section{Faktor-faktor Sosial}

Kelompok ini juga mempengaruhi perilaku konsumen dalam pembeliannya, dan sering dijadikan pedoman oleh konsumen dalam bertingkah laku, oleh karena itu selalu mengawasi kelompok tersebut baik tingkah laku fisik maupun mentalnya. Interaksi mereka sering dilakukan secara individual, sehinnga seseorang sering terpengaruh oleh orang lain untuk membeli sesuatu. Kelompok ini sering disebut dengan kelompok referensi. Yang termasuk dalam kelompok referensi ini adalah kelas puncan atas, kelas puncan bawah, kelas menengah atas, kelas menengah, kelas pekerja, kelas bawah atas dan kelas bawah rendah.

Faktor-faktor Intern Yang Mempengaruhi Perilaku Konsumen. 
Selain faktor yang mempengaruhi lingkungan ekstern, faktor-faktor psikologis yang berasal dari proses intern individu sangat berpengaruh terhadap perilaku konsumen. Adapun faktor-faktor psikologis yang menjadi faktor dasar dalam perilaku konsumen antara lain adalah:

\section{a. Motivasi}

Setiap kegiatan yang dilakukan seseorang itu didorong oleh kebutuhan dari dalam diri orang tersebut, kekuatan pendorong inilah yang disebut dengan motivasi. Secara definisi motivasi dapat diartikan adalah suatu dorongan kebutuhan dan keinginan individu yang diarahkan pada tujuan untuk memperoleh kepuasan. Bagi manajer marketing sangatlah penting untuk mengetahui perilaku konsumen terhadap produk, sebab hal ini akan mempengaruhi politik marketing perusahaan.

\section{b. Persepsi}

Persepsi atau tanggapan adalah suatu proses dimana konsumen menyadari dan menginterprestasikan aspek lingkungannya, atau dapat dikatakan sebagai proses penerimaan adanya rangsangan atau stimulus dalam lingkungan intern dan ekstern, sehingga tanggapan (persepsi) bersifat aktif. Proses persepsi ini dibagi tiga yaitu; Selective eksposure, Selectiv Distortion dan Selective retention.

\section{c. Belajar}

Proses belajar apabila seseorang ingin menanggapi dan memperoleh suatu kepuasan, sebaliknya proses belajar akan terjadi apabila seseorang akan merasa dikecewakan oleh produk yang kurang baik. Teori yang mempelajari perilaku konsumen melalui proses belajar disebut belajar. Dalam praktek penggunaan teori belajar dalam program marketing dapat berupa pemberian contoh barang secara cuma-cuma.

\section{d. Kepribadian dan konsep diri}

Kepribadian dapat didefinisikan sebagai organisasi dan faktor biologis, psikologis dan sosiologis yang mendasari perilaku individu. Menurut Swasta (2003: 86) ada tiga unsur pokok kepribadian, antara lain yaitu: pengetahuan, 
perasaan dan dorongan naluri. Ketiga unsur pribadi tersebut dapat tercermin atau diamati lewat aktivitas, minat dan opini mereka, dengan menggunakan risert motivasi. Konsep diri yaitu : Individu yang diterima oleh individu itu sendiri dalam kerangka kehidupannya dalam suatu masyarakat yang menentukan.

\section{e. Sikap}

Sikap adalah kecenderungan yang dipelajari untuk bereaksi terhadap penawaran produk, dalam masalah yang baik atau yang kurang baik secara konsistan. Dengan mempelajari sikap konsumen terhadap produk yang dihasilkan, diharapkan akan dapat menentukan apa yang dilakukan dimasa yang akan dating.

\section{Perilaku Konsumen dan Teori-Teori Perilaku Konsumen}

\section{Perilaku Konsumen}

Tujuan kegiatan marketing adalah untuk mempengaruhi pembeli untuk bersedia membeli barang dan jasa perusahaan. Hal ini sangat penting bagi manajer marketing untuk memahami mengapa dan bagaimana perilaku konsumen tersebut demikian, sehingga perusahaan dapat mengembangkan, menentukan harga, mempromosikan dan mendistribusikan produknya secara baik

\section{Metode Penelitian}

\section{Rancangan Penelitian}

Penelitian ini menggunakan paradigma positivistik (fakta sosial) dengan pendekatan kualitatif, yaitu paradigma yang menganggap realitas itu sebagai sesuatu yang empiris atau benar - benar nyata dan dapat diobservasi,bertujuan untuk menjelaskan, penyelidikan (ekplorasi), deskripsi, dan juga proses terjadinya. Metode yang dilakukan dengan cara mengumpulkan, memperiapkan serta menganalisis data sehingga mendapat gambaran yang jelas mengenai masalah yang diteliti. Pendekatan kualitatif deskriptif bertujuan untuk mendeskripsikan secara sistematis, faktual dan akurat, mengenai fakta - fakta, sifat - sifat serta hubungan antara fenomena yang diteliti. Paradigma positivistik dengan pendekatan kualitatif yang digunakan lebih menekankan pada penjelasan secara rinci dan mendalam mengenai objek studi serta mempelajari salah satu proses management 
dan operasional bank s mengenai penentuan keputusan beserta faktor yang mempengaruhinya dalam pembiayaan kredit KPR.

Miles dan Huberman (1984) mengemukakan bahwa aktivitas dalam analisis data. Yaitu pengumpulan data (data Collection), reduki data (data reduction), penyajian data (data display) dan penarikan Kesimpulan (Conclussion). Pendekatan kualitatif yang digunakan lebih menekankan pada penjelasan secara rinci dan mendalam mengenai obyek studi serta mempelajari proses management dan operasional Bank Syariah dan juga menganalisis faktor- faktor yang dipertimbangkan dan juga prosedur dalam penetuan penentuan keputusan beserta faktor yang mempengaruhinya dalam pembiayaan kredit KPR di BTN Jember.

\section{Obyek Penelitian}

Obyek penelitian yang digunakan adalah Nasabah BTN Cabang Jember yang berlokasi di Jl.A.Yani Jember

\section{Teknik Pengambilan Sampel}

Dalam teknik pengambilan sampel ini akan dijelaskan antara sampel dan populasi. Populasi adalah jumlah dari seluruh subyek yang akan diteliti. Sedangkan yang dimaksud populasi dalam penelitian ini adalah konsumen yang mengambil kredit KPR pada PT. Bank Tabungan Negara (Persero) Tbk. Cabang Jember. Jumlah populasi adalah sebanyak 200 responden

Sampel Dalam penelitian ini pengambilan sampel menggunakan metode non probability quota sampling yaitu suatu metode pengambilan sampel dimana subyek yang akan diteliti ditentukan terlebih dahulu atas jumlahya. Jumlah sampel sebesar $50 \%$ dari jumlah responden yaitu sebanyak 100 sampel yang terbagi dalam beberapa kategori yaitu :

a. Kategori pegawai swasta jumlah populasi sebanyak 90 orang sedangkan jumlah sampel sebanyak 45 orang

b. Kategori pegawai negeri jumlah popolasi sebanyak 60 orang sedangkan jumlah sampel sebanyak 30 orang 
c. Kategori pedagang jumlah populasi sebanyak 30 orang sedangkan jumlah sampel sebanyak 15 orang

d. Kategori wiraswasta jumlah populasi sebanyak 20 orang sedangkan jumlah sampel sebanyak 10 orang

\section{Metode Pengumpulan Data}

Adapun metode pengumpulan data yang digunakan dalam penelitian ini antara lain ialah :

1) Interview adalah suatu metode pengumpulan data diperoleh dengan jalan tatap muka langsung serta mengadakan tanya tawab langsung dengan pimpinan, Staf dan karyawan terhadap permasalahan yang berkaitan dengan penelitian. Datadata yang diharapkan pada metode ini antara lain sejarah perusahaan, struktur organisasi, domisili perusahaan dan lain sebagainya.

2) Observasi adalah metode pengumpulan data diperoleh dengan jalan mengadakan peninjauan secara langsung terhadap obyek penelitian serta mengadakan pencatatan secara sistematis terhadap berbagai hal yang berkaitan dengan penelitian. Data-data yang diperoleh pada metode ini antara lain jumlah konsumen, persyaratan kredit, luas daerah pemasaran dan lain sebagainya.

3) Kuessioner yaitu metode pengumpulan data yang dapat dilakukan dengan cara menyebarkan atau memberikan selebaran yang berisi tentang faktor-faktor yang akan dianalisis kepada para konsumen. Data-data yang diperoleh pada metode ini yaitu hasil kuessioner oleh nasabah yang mengambil kredit KPR pada PT. Bank Tabungan Negara (Persero) Tbk cabang Jember.

\section{Definisi Operasional Variabel}

a. Dalam penelitian ini faktor dependennya adalah keputusan konsumen yang mengambil kredit KPR pada PT. Bank Tabungan Negara (Persero) Tbk cabang Jember. Sedangkan faktor independenya adalah faktor persyaratan kredit, faktor suku bunga kredit dan faktor subsidi angsuran kredit.

b. Perilaku konsumen adalah sesuatu yang menjadi sifat (kebiasaan) seseorang (kelompok) didalam usaha untuk mendapatkan suatu keinginan. (Poerwadarminta, 2007 : 11).

c. Keputusan konsumen adalah sesuatu yang menjadi sifat (kebiasaan) 
seseorang (kelompok) didalam usaha untuk mendapatkan suatu keinginan.

\section{Metode Analisis Data}

Analisis data yang digunakan dalam penelitian ini adalah analisis Chi-square dan analisis derajat contingency, hal ini dikarenakan data yang akan dianalisis berdasarkan hasil quessioner.

\section{Analisis Chi-Kuadrat}

Untuk mengetahui apakah faktor persyaratan, suku bunga kredit dan subsidi angsuran kredir berpengaruh terhadap keputusan konsumen, digunakan analisis Chi-kuadrat, dengan rumus (Djarwanto, 2001: 281)

$$
\begin{gathered}
\left(\mathrm{E}_{0}-\mathrm{E}\right)^{2} \\
\mathrm{X}^{2}=-------
\end{gathered}
$$

Dimana :

$$
\mathrm{E}=\frac{\mathrm{E} \text { baris }}{\mathrm{E} \text { total }} \mathrm{x}(\Delta \mathrm{E} \text { baris })
$$

Keterangan :

$$
\begin{aligned}
& X=\text { Chi-kuadrat } \\
& E_{0}=\text { frekwensi yang diperoleh dari responden } \\
& E=\text { frekwensi yang diharapkan dari sample }
\end{aligned}
$$

b. Untuk mengetahui faktor yang paling dominan digunakan analisis derajat kontingensi, yaitu dengan rumus : (Djarwanto, 2001 : 287)

$$
C=\sqrt{---\cdot--}
$$

Keterangan :

$\mathrm{C}=$ derajat contingensi

$\mathrm{X}^{2}=$ nilai dari chi kuadrat

$\mathrm{N}=$ jumlah total frekwensi

\section{Hasil Dan Pembahasan}

\section{Hasil Penelitian}

Responden adalah nasabah yang mengambil kredit KPR pada PT. Bank Tabungan 
Negara (Persero) Tbk cabang Jember. Jumlah responden yang di jadikan sampel sebanyak 100 responden. Dari jumlah tersebut responden di bedakan dalam 4 (empat) kategori yaitu (1) Pegawai swasta, jumlah sampel untuk kategori pegawai swasta sebanyak 45 responden, (2) Pegawai Negeri Sipil, jumlah sampel untuk kategori Pegawai Negeri Sipil sebanyak 30 responden, (3) Pedagang, jumlah sampel untuk kategori pedagang sebanyak 15 responden dan (4) Wiraswasta, jumlah sampel untuk kategori wiraswasta sebanyak 10 responden. Sedangkan faktor-faktor yang di analisis sebanyak (tiga) faktor antara lain yaitu faktor persyaratan mengajukan kredit, faktor suku bunga kredit dan faktor subsidi angsuran. Adapun hasil kuessioner dari masing-masing faktor seperti yang terlihat pada tabel 3.2 sampai dengan tabel 3.4. berikut ini :

Tabel 5.1. PT. BANK TABUNGAN NEGARA (Persero) Tbk Jember Faktor Persyaratan Pengajuan Kredit KPR

\begin{tabular}{|c|c|c|c|c|c|c|}
\hline \multirow{2}{*}{$\begin{array}{l}\text { Kategori : } \\
\text { Faktor persyara tan kredit } \\
\text { KPR. }\end{array}$} & \multicolumn{4}{|c|}{ Pembagian Kategori Responden } & \multirow[b]{2}{*}{ Jml. } & \multirow[b]{2}{*}{$(\%)$} \\
\hline & $\mathrm{A}$ & B & $\mathbf{C}$ & D & & \\
\hline Sangat Mudah & 24 & 14 & 8 & 5 & 51 & $51 \%$ \\
\hline Mudah & 10 & 8 & 4 & 3 & 25 & $25 \%$ \\
\hline Cukup Mudah & 7 & 5 & 2 & 1 & 15 & $15 \%$ \\
\hline Berbelit-belit & 4 & 3 & 1 & 1 & 9 & $9 \%$ \\
\hline Jumlah & 45 & 30 & 15 & $\mathbf{1 0}$ & 100 & $100 \%$ \\
\hline
\end{tabular}

Sumber data : Hasil Kuessioner
Keterangan : $\mathrm{A}=$ Kelompok pegawai swasta
$\mathrm{B}=$ Kelompok PNS
$\mathrm{C}=$ kelompok pedagang
$\mathrm{C}=$ kelompok wiraswasta

Berdasarkan tabel 5.1. diatas yaitu tentang faktor persyaratan pengajuan kredit, KPR sebanyak 51 responden $(51 \%)$ menyatakan bahwa persyaratan pengajuan kredit KPR pada PT. Bank Tabungan Negara (Persero) Tbk cabang Jember "sangat mudah", sebanyak 25 responden (25\%) menyatakan bahwa persyaratan pengajuan kredit KPR "Mudah", sebanyak 15 responden (15\%) menyatakan bahwa persyaratan pengajuan kredit KPR “cukup mudah" dan sebanyak 10 responden (10\%) menyatakan bahwa persyaratan pengajuan kredit KPR "berbelit-belit".

Tabel 5.2 :PT. BANK TABUNGAN NEGARA (Persero) Tbk Jember Faktor Suku Bunga Kredit KPR

\begin{tabular}{|l|c|c|c|c|c|c|}
\hline Kategori : $\begin{array}{l}\text { Faktor Suku } \\
\text { Bunga Kredit }\end{array}$ & A & B & C & D & Jumlah & (\%) \\
\cline { 2 - 7 } & & 13 & 8 & 6 & 47 & $\mathbf{4 7 \%}$ \\
\hline Sgt. Rendah & 20 & & & & \\
\hline
\end{tabular}




\begin{tabular}{|l|c|c|c|c|c|c|}
\hline Rendah & 13 & 8 & 3 & 2 & 26 & $\mathbf{2 6 \%}$ \\
Ckp Rendah & 8 & 6 & 3 & 1 & 18 & $\mathbf{1 8 \%}$ \\
Tinggi & 4 & 3 & 1 & 1 & 9 & $\mathbf{9 \%}$ \\
\hline Jumlah & $\mathbf{4 5}$ & $\mathbf{3 0}$ & $\mathbf{1 5}$ & $\mathbf{1 0}$ & $\mathbf{1 0 0}$ & $\mathbf{1 0 0 \%}$ \\
\hline
\end{tabular}

Sumber data : Hasil Kuessioner

Keterangan : $\quad \mathrm{A}=$ Kelompok pegawai swasta $\mathrm{B}=$ Kelompok PNS

$\mathrm{C}=$ kelompok pedagang $\quad \mathrm{C}=$ kelompok wiraswasta

Berdasarkan tabel 5.2 diatas yaitu tentang faktor suku bunga kredit, sebanyak 47 responden (47\%) menyatakan bahwa suku bunga kredit KPR yang terdapat pada PT. Bank Tabungan Negara (Persero) Tbk cabang Jember "sangat rendah", sebanyak 26 responden (26\%) menyatakan suku bunga kredit KPR "rendah", sebanyak 18 responden (18\%) menyatakan bahwa suku bunga kredit KPR “cukup rendah" dan sebanyak 9 responden (9\%) menyatakan bahwa suku bunga kredit KPR yang terdapat pada PT. Bank Tabungan Negara (Persero) Tbk cabang Jember "tinggi".

Tabel 5.3 : PT. BANK TABUNGAN NEGARA (Persero) Tbk Jember

\begin{tabular}{|c|c|c|c|c|c|c|}
\hline \multirow{2}{*}{$\begin{array}{l}\text { Kategori : } \\
\text { Faktor Subsidi } \\
\text { Angsuran Kredit }\end{array}$} & \multicolumn{4}{|c|}{ Pembagian Kategori Responden } & \multirow{2}{*}{ Jml. } & \multirow{2}{*}{$(\%)$} \\
\hline & $\mathbf{A}$ & B & $\mathbf{C}$ & $\mathbf{D}$ & & \\
\hline Sangat Baik & 22 & 12 & 7 & 5 & 46 & $46 \%$ \\
\hline Baik & 13 & 9 & 4 & 2 & 28 & $28 \%$ \\
\hline Cukup Baik & 6 & 6 & 3 & 2 & 17 & $17 \%$ \\
\hline \multirow[t]{2}{*}{ Tidak Baik } & 4 & 3 & 1 & 1 & 9 & $9 \%$ \\
\hline & 45 & 30 & 15 & 10 & 100 & $100 \%$ \\
\hline
\end{tabular}

Sumber data : Hasil Kuessioner

Keterangan : $\mathrm{A}=$ Kelompok pegawai swasta $\quad \mathrm{B}=$ Kelompok PNS

$\mathrm{C}=$ kelompok pedagang $\quad \mathrm{C}=$ kelompok wiraswasta

Berdasarkan tabel 5.3 diatas yaitu tentang faktor subsidi angsuran kredit KPR, sebanyak 46 responden (46\%) menyatakan bahwa subsidi angsuran kredit pada PT. Bank Tabungan Negara (Persero) Tbk cabang Jember "sangat baik", sebanyak 28 responden (28\%) menyatakan bahwa subsidi angsuran kredir "baik", sebanyak 17 responden (17\%) menyatakan bahwa subsidi angsuran kredit "cukup 
baik" dan sebanyak 9 responden (9\%) menyatakan bahwa subsidi angsuran kredit "tidak baik".

\section{Pembahasan}

\section{Analisis Chi-kuadrat}

Analisis Chi-kuadrat digunakan untuk mengetahui hubungan antara faktor-faktor yang mempengaruhi perilaku konsumen (yang terdiri dari (1) persyaratan, (2) suku bunga kredit dan (3) subsidi angsuran kredit) terhadap keputusan konsumen dalam mengambil kredit KPR pada PT. Bank Tabungan Negara Tbk Cabang Jember. Adapun penjelasannya sebagai berikut :

\section{Faktor Persyaratan Pengajuan Kredit}

Dengan berdasarkan pada tabel 5.1 tentang faktor persyaratan pengajuan kredit, maka untuk mengetahui apakah terdapat pengaruh yang signifikan terhadap keputusan konsumen dalam mengambil kredit KPR pada PT. Bank Tabungan Negara Tbk cabang Jember, dapat ditentukan dengan perhitungan sebagai berikut :

a. Ho $: \mathrm{P}_{11}=\mathrm{P}_{12}=\mathrm{P}_{13}=\mathrm{P}_{14}$

$\mathrm{P}_{21}=\mathrm{P}_{22}=\mathrm{P}_{23}=\mathrm{P}_{24}$

$\mathrm{P}_{31}=\mathrm{P}_{32}=\mathrm{P}_{33}=\mathrm{P}_{34}$

$\mathrm{P}_{41}=\mathrm{P}_{42}=\mathrm{P}_{43}=\mathrm{P}_{44}$

(tidak terdapat perbedaan dalam variabel)

Hi : Terdapat perbedaan dalam variable

b. Level of significant $(\alpha)=\mathbf{0 , 0 5}$

$\mathrm{X}^{2}=((0,05 ;(\mathrm{r}-1)(\mathrm{k}-1))=((0,05 ;(4-1)(4-1))=16,919$

c. Kriteria pengujian :

Ho ditolak apabila nilai $X^{2}<16,919$ (berpengaruh)

Ho diterima apabila nilai $X^{2}>16,919$ (tidak berpengaruh)

Perhitungan $\mathrm{X}^{2}$ dari sample-samplenya menghasilkan nilai sebesar 0,87 (lampiran 1)

Dari hasil perhitungan diatas diperoleh nilai bahwa $X^{2}$ hitung $=0,87$ yang berarti lebih kecil dari $\mathrm{X}^{2}$ tabel yaitu sebesar 16,919, maka Ho ditolak yang berarti terdapat pengaruh yang significant antara faktor persyaratan pengajuan kredit terhadap keputusan konsumen dalam mengambil kredit KPR pada PT. Bank Tabungan Negara Tbk Cabang Jember. 


\section{Faktor Suku Bunga Kredit}

Dengan berdasarkan pada tabel 5.3 tentang faktor suku bunga kredit, maka untuk mengetahui apakah terdapat pengaruh yang signifikan terhadap keputusan konsumen dalam mengambil kredit KPR pada PT. Bank Tabungan Negara Tbk cabang Jember, dapat ditentukan dengan perhitungan sebagai berikut :

a. $\quad$ Ho $: \mathrm{P}_{11}=\mathrm{P}_{12}=\mathrm{P}_{13}=\mathrm{P}_{14}$

$\mathrm{P}_{21}=\mathrm{P}_{22}=\mathrm{P}_{23}=\mathrm{P}_{24}$

$\mathrm{P}_{31}=\mathrm{P}_{32}=\mathrm{P}_{33}=\mathrm{P}_{34}$

$\mathrm{P}_{41}=\mathrm{P}_{42}=\mathrm{P}_{43}=\mathrm{P}_{44}$

(tidak terdapat perbedaan dalam variabel)

Hi : Terdapat perbedaan dalam variable

b. Level of significant $(\alpha)=\mathbf{0 , 0 5}$

$\mathrm{X}^{2}=((0,05 ;(\mathrm{r}-1)(\mathrm{k}-1))=((0,05 ;(4-1)(4-1))=16,919$

\section{c. Kriteria pengujian :}

Ho ditolak apabila nilai $\mathrm{X}^{2}<16,919$ (berpengaruh)

Ho diterima apabila nilai $X^{2}>16,919$ (tidak berpengaruh)

Perhitungan $X^{2}$ dari sample-samplenya menghasilkan nilai sebesar 2,403 (lampiran 2)

Dari hasil perhitungan diatas diperoleh nilai bahwa Chi-square faktor suku bunga kredit adalah sebesar $=2,403$ yang berarti lebih kecil dari nilai $X^{2}$ tabel yaitu sebesar 16,919, maka Ho ditolak yang berarti terdapat pengaruh yang significant antara faktor suku bunga kredit terhadap keputusan konsumen dalam mengambil kredit KPR pada PT. Bank Tabungan Negara Tbk Cabang Jember.

\section{Faktor Subsidi Angsuran Kredit}

Dengan berdasarkan pada tabel 5.3 tentang faktor subsidi angsuran kredit, maka untuk mengetahui apakah terdapat pengaruh yang signifikan terhadap keputusan konsumen dalam mengambil kredit KPR pada PT. Bank Tabungan Negara Tbk cabang Jember, dapat ditentukan dengan perhitungan sebagai berikut :

a. Ho : $\mathrm{P}_{11}=\mathrm{P}_{12}=\mathrm{P}_{13}=\mathrm{P}_{14}$

$$
\begin{aligned}
& \mathrm{P}_{21}=\mathrm{P}_{22}=\mathrm{P}_{23}=\mathrm{P}_{24} \\
& \mathrm{P}_{31}=\mathrm{P}_{32}=\mathrm{P}_{33}=\mathrm{P}_{34} \\
& \mathrm{P}_{41}=\mathrm{P}_{42}=\mathrm{P}_{43}=\mathrm{P}_{44}
\end{aligned}
$$


(tidak terdapat perbedaan dalam variabel)

Hi : Terdapat perbedaan dalam variable

b.Level of significant $(\alpha)=\mathbf{0 , 0 5}$

$\mathrm{X}^{2}=((0,05 ;(\mathrm{r}-1)(\mathrm{k}-1))=((0,05 ;(4-1)(4-1))=16,919$

c.Kriteria pengujian :

Ho ditolak apabila nilai $X^{2}<16,919$ (berpengaruh)

Ho diterima apabila nilai $X^{2}>16,919$ (tidak berpengaruh)

d. Perhitungan $\mathrm{X}^{2}$ dari sample-samplenya menghasilkan nilai sebesar $\mathbf{2 , 8 2 2}$ (lampiran 3)

Dari hasil perhitungan diatas diperoleh nilai bahwa Chi-square faktor subsidi angsuran kredit kredit adalah sebesar 2,822 yang berarti lebih kecil dari nilai $\mathrm{X}^{2}$ tabel yaitu sebesar 16,919, maka Ho ditolak yang berarti terdapat pengaruh yang significant antara faktor subsidi angsuran kredit terhadap keputusan responden dalam mengambil kredit pada PT. Bank Tabungan Negara Tbk cabang Jember.

\section{Analisis Coeficient Contingency}

Untuk mengetahui seberapa besar pengaruh dari faktor persyaratan pengajuan kredit, faktor suku bunga kredit dan faktor subsidi angsuran kredit terhadap keputusan konsumen dalam mengambil kredit KPR pada PT. Bank Tabungan Negara Tbk cabang Jember, dapat diketahui dengan menggunakan analisis Coeficient Contingency yang perhitungannya adalah sebagai berikut :

\section{Pengaruh faktor persyaratan pengajuan kredit.}

Berdasarkan perhitungan pada lampiran 1, nilai derajat contingency $(\mathrm{C})=$ 0,093, yang menunjukkan bahwa ada pengaruh yang positif antara faktor persyaratan pengajuan kredit terhadap keputusan konsumen dalam mengambil kredit. Nilai $\mathrm{C}=0,093$ sedangkan nilai $\mathrm{C}$ maks $=0,89$, berarti terdapat hubungan yang searah namun lemah antara faktor persyaratan pengajuan kredit dengan keputusan konsumen dalam mengambil kredit KPR pada PT. Bank Tabungan Negara Tbk cabang Jember.

\section{Pengaruh suku bunga kredit}

Berdasarkan perhitungan pada lampiran 2, nilai derajat contingency $(\mathrm{C})=$ 0,153, yang menunjukkan bahwa ada pengaruh yang positif antara faktor suku 
bunga kredit terhadap keputusan konsumen dalam mengambil kredit KPR pada PT. Bank Tabungan Negara Tbk cabang Jember. Nilai $\mathrm{C}=0,153$ sedangkan nilai $\mathrm{C}$ maks $=0,89$, berarti terdapat hubungan yang searah namun lemah antara faktor suku bunga kredit terhadap keputusan konsumen dalam mengambil kredit KPR..

\section{Pengaruh Faktor Subsidi Angsuran Kredit}

Berdasarkan perhitungan pada lampiran 3, nilai derajat contingency $(\mathrm{C})=$ 0,166, yang menunjukkan bahwa ada pengaruh yang positif antara faktor subsidi angsuran kredit terhadap keputusan konsumen dalam mengambil kredit KPR pada PT. Bank Tabungan Negara Tbk cabang Jember. Nilai C $=0,458$ sedangkan nilai $\mathrm{C}$ maks $=0,8$, berarti terdapat hubungan yang searah namun lemah antara faktor subsidi angsuran kredit kredit terhadap keputusan konsumen dalam mengambil kredit KPR pada PT. Bank Tabungan Negara Tbk cabang Jember.

\section{Kesimpulan}

Berdasarkan hasil perhitungan tentang faktor-faktor yang mempengaruhi perilaku nasabah dalam mengambil kredit pada PT. Bank Tabungan Negara Tbk cabang Jember dengan menggunakan beberapa alat analisis, maka dapat ditarik suatu kesimpulan sebagai berikut :

a. Berdasarkan hasil perhitungan dengan menggunakan alat analisis Chikuadrat, maka faktor persyaratan pengajuan kredit, faktor suku bunga kredit dan faktor realisasi pencairan kredit, terdapat hubungan yang signifikan terhadap keputusan nasabah dalam mengambil kredit pada PT. Bank Tabungan Negara Tbk cabang Jember, hal tersebut dibuktikan dengan hasil analisis bahwa nilai $X^{2}$ (hitung) $<X^{2}$ (tabel), dimana nilai $X^{2}$ (hitung) dari faktor persyaratan pengajuan kredit sebesar 0,87 , nilai $X^{2}$ (hitung) dari faktor suku bunga kredit sebesar 2,403 dan untuk $\mathrm{X}^{2}$ (hitung) dari faktor realisasi pencairan kredit sebesar 2,822, sedangkan $\mathrm{X}^{2}$ (tabel) sebesar 16,919.

b. Berdasarkan hasil perhitungan dengan menggunakan alat analisis Coeficient Contingency, faktor-faktor yang mempengaruhi keputusan nasabah dalam mengambil kredit pada PT. Bank Tabungan Negara Tbk cabang Jember diperoleh hasil yaitu faktor persyaratan pengajuan kredit sebesar 0,093, faktor 
suku bunga kredit sebesar 0,153 dan faktor realisasi pencairan kredit sebesar 0,166 . Oleh karena nilai-nilai hasil perhitungan tersebut masih dibawah 0,5 maka faktor-faktor tersebut dinyatakan memiliki hubungan yang positif. Dari ketiga faktor-faktor yang mempengaruhi perilaku nasabah faktor persyaratan pengajuan kredit berpengaeuh sebesar 0,87, faktor suku bunga kredit berpengaruh sebesar 2,403 dan faktor realisasi pencairan kredit berpengaruh sebesar 2,822.

\section{Saran-saran}

Berdasarkan hasil kesimpulan di atas maka dapat diberikan beberapa saran yang bermanfaat bagi perusahaan, antara lain yaitu :

a. Diharapkan pihak perusahaan dalam hal ini PT. Bank Tabungan Negara Tbk cabang Jember untuk lebih memperhatikan kembali atas perilaku dan motif nasabah, terutama terhadap faktor-faktor yang mempengaruhi nasabah dalam mengambil kredit.

b. Untuk meningkatkan jumlah nasabah, diharapkan pihak perusahaan lebih meningkatkan lagi baik kegiatan promosi, pelayanan, prosedur maupun terhadap faktor-faktor lain sehingga dapat menarik minat responden untuk menjadi nasabah khususnya di dalam pengajuan mengambilan kredit.

\section{Daftar Pustaka}

Basu Swastha, 2002, Manajemen Pemasaran Modern, Edisi Ketiga, Penerbit BPFE-UGM, Yogyakarta.

Basu Swastha, 2003, Manajemen Pemasaran Modern, Edisi Revisi, Penerbit BPFE-UGM, Yogyakarta.

Djarwanto Ps, 2001, Pengantar Metode Statistik, Penerbit BPFE-UGM, Yogyakarta.

H. Hadori Nawawi, 2003, Metode Penelitian Bidang Sosial, Penerbit Gajah Mada University Press, Yogyakarta.

Philip Kotler, 2004, Azas-azas Marketing, Edisi Ketiga, Penerbit Liberty, Yogyakarta.

Poerwadrminta, 2007, Kamus Umum Bahasa Indonesia, Penerbit Balai Pustaka, Jakarta 